\title{
"The Great Classicist Symphonic Movements of Beethoven... Can Be Ideally So Heard as Lasting Just a Moment:" Adorno on Musical Time
}

\begin{abstract}
Ilias Giannopoulos
National University of Athens

In the context of his thoughts on the relationship between music and time in his Musical Writings, Adorno refers often to the above quoted thesis. This paradoxicality, attributed to particular symphonies of Beethoven, tends to become a fixed idea in the context of his thoughts on musical time. Adorno adopts Hegel's understanding of time as process of permanent overcoming of instants. He finds an analogy between instant and musical motive, based on the common, in Hegel's and Beethoven's systems, notion of the working-out of an idea and of a musical structure respectively. He then tries to include in the process of becoming extended and reappearing formal parts, such as themes and expositions. How could he find a convergence between permanent formal growth and persistence of formal parts, which distinguishes a musical work from an improvisation? In order to transcend this immanent antinomy, he applies Hegelian logical principles.
\end{abstract}

Keywords: philosophical aesthetics, philosophy of music, Adorno, Hegel, philosophy of time

\section{Introduction}

If consideration is given to different passages from Adorno's musical writings, such as "Kriterien der neuen Musik," “On Some Relationships between Music and Painting,"2 "Zweite Nachtmusik,"3 "Über die musikalische Verwendung des Radios,", and, above all, to the axiomatic formulation in Aesthetic Theory, "Every Artwork is an Instant," Moment/Augenblick) is one of the cardinal conceptions of his theory of art. In general, Adorno employs different expressions, ${ }^{6}$ to express a temporal, structural, and transcendental mode of the artwork's objectification and aesthetic experience. ${ }^{7}$ In Aesthetic Theory, Adorno also uses metaphors to express the sudden, momentary (even "shuddering") character of the artwork: "The artwork as appearance is most closely resembled by the apparition, the heavenly vision... The phenomenon of fireworks is prototypical for

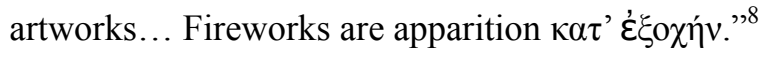

Adorno's insistence on the use of the notions "moment" and "instant" in the context of his exploration of the notion of the aesthetic experience, especially of particular musical works, ${ }^{9}$ tends to imply a quantity of measured time. That means, his axiomatic formulation and, in particular, the paradoxical claim in the quotation

Ilias Giannopoulos, Ph.D., independent scholar, Department of Music Studies, School of Philosophy, National University of Athens, Greece; main research fields: Philosophical Aesthetics, Critical Theory, Phenomenology (Time Consciousness), and Musicology. 
that appears in the title of this paper ${ }^{10}$ could be taken literally. He relies namely on the use of time quanta (e.g., minutes) in relation to the "virtual effect" of the duration of Beethoven's symphonic movements. ${ }^{11}$ In so far as his claim refers to a state of subjective impression of the duration of particular - and according to him paradigmatic, for their temporal structure-musical works (of the classical era), this "virtual effect" has also been explored from compositional and, tangentially, cognitive perspectives: During the late 1950s, and not by referring only to their own compositions, Messiaen and Stockhausen highlighted the relationship that exists between the "perception of the present duration" and the notion of the event ("événement" and "Vorgang," respectively); density of musical events (in addition, according to Stockhausen, the grade of their difference or even contrast) created an impression of shortened "experienced duration" 12 or "experienced time" 13 in relation to the perception of the musical presence. Both composers claim that in this case, the listener, being overwhelmed by accumulated structural data, has not the time for reflection that could cause the impression of temporal extension. From a music-philosophical point of view, Adorno introduces the notion of intensive time, as referring to "density of musical events" that leads to the above mentioned "virtual effect" and paradoxical claim. As will be stated in part two of this paper, in the context of intensity or density of musical events, aesthetic (that is subjective) and measured time can find a convergence in crucial, "pregnant" moments.

\section{From Subjective to Objective Moment}

Adorno takes an additional, work-immanent path in Musikalische Schriften and in Beethoven: Philosophie der Musik concerning the understanding of the moment. In Aesthetic Theory, he ascertains the value of the subjective moment, the instantaneous "shock aroused by important works"14 in relation to the above mentioned metaphors for their manifestation. He stands in the tradition of what Karl Heinz Bohrer considers as "The generation of the "dangerous instant." 15 But in essays like "Form in der neuen Musik" of Musikalische Schriften and in Beethoven: Philosophie der Musik, he attempts to discover and outline structural work-immanent conditions of a time-overcoming, instantaneous work-totality. He tries to support paradoxical occurrences, like this in the paper's title, based on materialistic observations. Appropriate paradigms for such paradoxical occurrences are processual, that is, temporal art-forms, like music; any claim of reified totality and instantaneous intuitive perception of this totality in the case of temporal art-forms implies, namely, severe difficulties. What kind of moment could represent totality in a temporal art-form?

Adorno mentions often in his musical writings such moments, when dynamic temporal succession interacts with "symphonic" formal contraction to intensive standstills. In this context, he also introduces the notion of the "nodal point" (Knoten) to explain the "reduction of the complete unfolding (Gesamtverlauf) of the form" in Webern's works (opp. 7-11), “... whose archetype stems from the extended symphonic movements of Viennese classicism." 16 Here, Adorno, the dialectical thinker, "reads the past in terms of the present and the present in terms of the past;" movements and reduction of a virtual "Gesamtverlauf" in Webern's works through superposed vectors of symmetry ${ }^{18}$ converge, though the music-historical distance, in the common phenomenon of intensity of musical events. Such super-positions, according to Stockhausen's conception, give the impression of shortened experienced time. ${ }^{19}$ Through the notion of the nodal point, Adorno outlines a structural, work-immanent condition that could support the previously mentioned paradoxical "virtual effect" on the listener. Formal totality, temporal extension and succession converge in such nodal points. 
Adorno considers intensive nodal points in "the great classicist symphonic movements of Beethoven" as standstills. However, he also detects standstills, as a consequence of temporal retardation and motivic-thematic reduction, in development sections of sonata-forms in works of the "late middle period," as are, according to him, Archduke Trio and Pastoral Symphony. More important, in works of the late style, he detects enigmatic standstills in moments of silence. Perhaps two fragments of Beethoven: The Philosophy of Music and of the essay "Late Style in Beethoven" help us to understand Adorno's distinction between two forms of standstill: While in works of Beethoven's early and middle period moments are bound "together as a unity - as simultaneous," 20 in works of the late style they are crucially "conjoined for better or worse," meaning not necessary for completion in totality; "for the mystery is between them, and cannot be invoked otherwise than in the figure they create together." ${ }^{21}$ So the distinction between such moments lies in their relationship to totality. In the first case, which constitutes the culmination of classicist structural coherence, moments can stand for totality. In works of Beethoven's "late middle period," where Adorno-from his historically holistic point of view-localizes the beginning of a fragmentation process of musical form, and, particularly, in works of the late style, this connection to totality is not imperative anymore.

Although Adorno liberates the apparition "from the burden of the empirical, which is the obligation of duration," 22 it would perhaps be not hyperbolic to claim that the quotation included in the paper's title refers also to a possibility of reinterpretation of the above mentioned metaphors, "firework" and "apparition" for a temporal and processual art-form, music; fireworks are sudden, instantaneous, and miraculous manifestations that "fade away" and this makes their "unsurpassable noblesse."23 The possibility of a sudden manifestation of a temporal artwork as totality, presupposes an instantaneous coherence of its parts should constitute an object that doesn't just comply with its processual and fleeting nature. According to Adorno, the idea of the firework is "the counterpart of a reification without which they (the temporal arts) would not exist and yet that degrades them." ${ }^{24}$ If Adorno aims to award consistency to such a counterpart, he has to enforce its internal structure, going beyond the legacy of the "heavenly vision" 25 of the "dangerous moment." As will be stated later in this article, he does it, based on Hegelian logical principles.

One could raise the objection that a clear distinction cannot always be found between subjective and objective (meaning, of the artwork) moment in Adorno's theory of art. In other words, is this a moment that can provide the work on the basis of its structure, or of the subject who perceives it and, even more, does it make any sense to distinguish between them? Indeed, according to Adorno's differentiated and quite idealized analysis of the levels of aesthetic experience, ${ }^{26}$ it can imply "a memento of the liquidation of the I, which, shaken, perceives its own limitedness and finitude," and object (artwork); aesthetic experience as "the shock aroused by important works... is the moment in which recipients forget themselves and disappear into the work." ${ }^{27}$ Berenson mentions that the observer of visual artworks "ceases to be his ordinary self, and the picture... is no longer outside himself. The two become one entity." 28 It appears that the aesthetic experience can ideally represent a challenge: The viewer (or audience) must merge with the artwork itself, and, especially, with its internal process. In particular, with respect to musical works, which after Hegel's Aesthetics have time as common constitutional principle with subjectivism, a convergence of objective and subjective level during the musical work's temporal unfolding and aural perception is possible through the elementary power of the tone; in its process of becoming and in its effect on the listener, the tone represents elementary the structure of the total, the work. ${ }^{29}$ 
In the following parts of this article, I will investigate the theoretical presuppositions of Adorno's paradoxical claim. Apart from the reflective synthesizing activity of subjective perception, which-from a Kantian point of view-manifests itself as an instantaneous "synthesis" of "apprehension,"30 I will explore conditions under which temporal extension and unfolding of a musical work (e.g., symphonic movements of Beethoven's middle period) could virtually be comprised in an instant and, in that way, provide a corresponding aural impression. It seems that Adorno's great contribution is his attempt to detect "without violence,"31 the possibility of the above mentioned paradoxical occurrence in concrete musical phenomena. In other words, he hopes to discover something (i.e. a grounded coherence of extended temporal objects) that may not be discovered in the case of phenomenological approaches that try to demonstrate the coherence and homogeneity-which Husserl demonstrates in the melody—in extended musical structures, even movements. ${ }^{32}$

\section{From Benjamin's “Similarity," “Constellation,” and “Aura” to Adorno's “Auto-mimesis” and "Synthesis"}

Frobenius has highlighted Benjamin's influence on Adorno's notion of the instant. ${ }^{33}$ In general, Benjamin's influence on Adorno is a very complex issue that is beyond the scope of this article. However, I will attempt to highlight particular aspects of this influence. As Frobenius states, the idea that such a crucial instant could represent (or provide a glimpse of) a kind of totality also appears in Benjamin's texts, "Doctrine of the Similar" and "On the Mimetic Faculty." Benjamin associates the perception of similarity with the (temporal quantity of a) moment: "The perception of similarity is in every case bound to a flashing up... to a moment in time." ${ }^{34}$ It "flits past" like a "constellation of stars." 35 According to Benjamin, the fleeting perception of similarity has been considered as an ability of mentalists. They believed that similarity could influence - in a process that reminds us of Adorno's "liquidation" between subject and object during the aesthetic experience - the fate of human beings who did not yet possess the ability to make subject-object distinction; their cognitive attitude towards the world was based on mimesis. Benjamin's interpretation of similarity refers, perhaps not explicitly, to both an existing, objective similarity or regularity found in the internal relationship of elements in the physical world, and to the process of mankind's subjective momentary adaptation to them, by mimesis. Adorno's allusions to Benjamin's notion of similarity are not always clear. ${ }^{36}$ Frobenius tries to correlate the general notion of mimesis that Benjamin introduces in the previously mentioned texts and also in his essay "On Some Motifs in Baudelaire," to Adorno's idea of auto-mimesis of the artwork in Aesthetic Theory. ${ }^{37}$ According to Adorno, in the process of rationalization of art, the archetypal "mimetic comportment" $" 38$ of which art constitutes a refuge, is being transformed to auto-mimesis of- and in the artwork. Mimesis in autonomous artworks ${ }^{39}$ is an inherent state of "semblance to themselves," "inherently every artwork desires identity with itself." 41 In this context, Adorno mentions Schönberg's statement, “... one paints a painting, not what it represents." ${ }^{, 42}$ This inherent attitude grounds on rationality: "Rationality in the artwork is the unity-founding, organizing element, not unrelated to the rationality that governs externally, but does not reflect its categorizing order.",43

The just-mentioned internal state of auto-mimesis of the autonomous artwork is connected to Adorno's materialistic reference to another Benjaminian notion: the aura. Adorno interprets technically aura as "uninterrupted sympathy of the parts with the whole." "44 How could the Benjaminian aura, as distant impression of an artwork, be supported by the latter's objective-materialistic characteristics? Adorno correlates aura (and the above mentioned "sympathy of the parts") to the notion of métier, which can be disclosed 
objectively by analysis: "The auratic element, paradoxically apparent and bound up with métier, is the memory of the hand that, tenderly, almost caressingly, passed over the contours of the work and, by articulating them, also mollified them. This relation of aura and métier can be brought out by analysis, which is itself lodged in métier." 45

It appears that for both thinkers, the terms (internal) "similarity" and "aura" refer to or support an idea of instantaneous totality which Adorno applies to the objectification of the artwork. Even if he did not adopt this notion from Benjamin, it is obvious that he made a radical contribution to it. Adorno explores presuppositions of a unified totality of an order which could be instantaneously grasped in a "state of similarity" by a subject. As far as it concerns the perceiving subject, Adorno's contribution to this Benjaminian notion is his idea of "self-denial" 46 of the subject during the aesthetic experience, and "liquidation" $" 47$ with the artwork-object. According to his extremely differentiated analysis, this is one of the "layers" of aesthetic experience. ${ }^{48}$ In the same time, by applying them to the artistic object, he transforms Benjamin's above-mentioned pre-rational notions (similarity, constellation, and aura) into a stronger state of internal coherence of the artwork-object; to the concept of synthesis that could be "brought out by analysis." 49 Thus, Adorno's development of Benjamin's notion of similarity to "auto-mimesis" refers not solely to a conjectural constellation (like this of the stars) and to a synthetic act of perception that forces these elements into alleged coherence:

The synthesis achieved by means of the artwork is not simply forced on its elements; rather, it recapitulates ${ }^{50}$ that in which these elements communicate with one another... The synthesis has its foundation in the spirit-distant material dimension of the work... ${ }^{51}$ This unites the aesthetic element of form with noncoercion. ${ }^{52}$ (Adorno, 7)

From the point of the subject, this relationship can be demonstrated by a notion of analysis that is "adequate to the work." The subject "grasps the relation of its (the work's) elements to each other processually rather than reducing them analytically to purported fundamental elements." ${ }^{, 53}$ Analysis and synthesis are consequences of a fundamental relationship and "communication" of the elements of the artwork: It is their integration into the process of becoming. By defining adequate analysis, Adorno understands this process both as external and internal; external means a historic process that forces artworks (their creation and perception) to transcend the past towards the future; internal means that this process, which can be "grasped technologically," is grounded on the artwork's elements" "incompleteness" and "insignificance." for Adorno as the very paradigm of artwork, his next step is to explore the ontological conditions of this internal process of becoming, namely the temporal relationships of its elements. But he goes even further: In order to understand artworks as "finished, molded objects," 55 he radicalizes the idea of internal communication of their elements by applying a Hegelian logical principle - the relationship of the whole to the parts.

Lessing's idea of the pregnant moment in Laokoon serves, perhaps through Benjamin, as an additional source of influence for Adorno. According to Lessing, the painter, as in our time the photographer, should choose the most appropriate instant and not just a transient; such an appropriate and comprehensive instant might depict and include the modes of time.

We can detect influences of Lessing's theory in Benjamin's idea that "the life undulating in it (the artwork) must appear petrified and as if spellbound on a single moment. ${ }^{56}$ Adorno's reference to hidden temporality in paintings in his essay "On Some Relationships between Music and Painting" also alludes to Lessing's influence. According to Lessing's theory, paintings depict pregnant moments of temporal processes. But since paintings belong to spatial art-forms, these processes are being represented simultaneously and contain, according to 
Adorno, internal relationships of tension. Adorno traces there "sedimented time." The "spatial nature (of a painting) for all that it appears to exist a priori" is a creation of time because, as he states, there is "no simultaneity without time. ${ }^{, 57}$ By analyzing extensively and repeatedly the process of the aesthetic experience in the Aesthetic Theory, Adorno refers explicitly to Lessing's aesthetics (and to Benjamin's dialectics of standstill) when he notes, "to experience art means to become conscious of its immanent process as an instant at a standstill; this may perhaps have nourished the central concept of Lessing's aesthetics, that of the 'pregnant moment." " 58 Adorno detects such "pregnant moments" also at nodal points ${ }^{59}$ of extreme accumulated power at the beginning of the recapitulation in sonata forms of Beethoven's middle period, as he notes in Aesthetic Theory, and makes more explicit in his musical writings. At such points, at the "crux of the dynamic form," the main theme reappears as a result in a new dynamic context, ${ }^{60}$ representing the dialectics between permanent formal process of becoming and identical persistence of formal parts, which distinguish a musical work from an improvisation.

\section{Sustainability versus Process of Becoming}

Adorno relies on the kinds of statements cited thus far to support his discussion of the problem of coherence in a processual art-form because music is the temporal art par excellence. Perhaps the most illuminating and comprehensive formulation that expresses Adorno's understanding of musical time is a truism referring to the "twofold character" of music, appearing again in his previously mentioned text, "On Some Relationships between Music and Painting:" "It (music) must create temporal relationships among its constituent parts, and justify their temporal relationships, synthesizing them through time. Conversely, it itself must act upon time, not lose itself to it; music must stem itself against the empty flood." ${ }^{\circ 1}$ As Klaus Kaehler states, according to Adorno, music constitutes a paradigm that he relies on to understand its ontological condition: time - as irreversible process and normative order — but also music's own modes of being, as temporal art-form. In so far, music demonstrates a relationship that exists between "objectification of time" and represented work. ${ }^{63}$

However, what does this relationship imply? Adorno claims that music "transpires within" irreversible time and "however little it coincides with the temporality of real experience, it too is irreversible." ${ }^{\circ 4} \mathrm{He}$ does not explore the nature of the flow of time. He considers it a fact, pointing out that music, as temporal art, is dynamic as are its material conditions. ${ }^{65}$ Although the undiscussed assumption of the existence of objective, irreversible time, as well as the existence of the time arrow might appear as simplifications, it appears for him to be an inevitable point of reference. Adorno's concern is to juxtapose to the external inevitable time flow, the work of music as temporal endurable (and insofar repeatable) object, in other words to point out a way "that the temporal arts... are to be interpreted. ${ }^{, 66} \mathrm{He}$ is totally aware of the integration into an external time flow of a temporal artwork that, at least virtually, contains time (duration). Despite explicit and prevalent idealizations of its temporality and the emphasis on the subjective "experienced time," ${ }^{67}$ music unfolds in objective time. It has countable duration, even if this temporal aspect is not always considered essential by composers, performers, and audiences. Apart from the fact that Adorno tries to understand artworks as "finished, molded objects," assumption that music is expression of experienced time implies a series of questions related to the temporal levels of consciousness. It leads to a regression ad infinitum that Husserl attempts to solve with the notions of "absolute subjectivity" and "primary consciousness." Without immersing ourselves in the labyrinths of layers of subjectivity emerging during the experience of time, we might just raise the following question: Why should 
a kind of, even simplified, temporal level of consciousness coincide with the temporal unfolding of the musical work? From another point of view, perhaps the most convincing answer is provided by Hegel in his Aesthetics: It is the elementary power of the musical tone that causes a fruitful coincidence because music and subjectivity have the same underlying principle - "time." ${ }^{, 69}$ Although Adorno often refers to the Bergsonian distinction between temps espace and temps durée and to "the end of musical Bergsonianism" of the Stravinsky-School, ${ }^{70}$ it appears that in his writings this distinction merely holds an axiological value.

What is, according to Adorno, the general formal concept of a musical work that first of all just confirms irreversible time? Adorno's assertion addresses musical works that are "free of any kind of repetition"71 (e.g., the second piece in Schönberg's opus 23), meaning works that clearly confirm the process of temporal succession by not having symmetrical formal design. ${ }^{72}$ Based on Adorno's interpretation, this small piece "coincides" with the "curve of its expression." ${ }^{73}$ However, this is still not enough. In addition to the direction of time, its dynamic character, and its irreversibility, Adorno highlights the importance of an exclusive order of succession, of causality. Actually, he considers, as anti-paradigms, open forms of works by avant-garde composers, such as Boulez's Third Piano Sonata and Stockhausen's Klavierstück XI, in which he scrutinizes the collapse of a normative musical syntax..$^{74}$ Adorno's concept of musical form is temporalized. It is not just an abstract spatialized (and in so far permutable) scheme. As he emphatically states, "Musical form is its (the music's) temporal order." a mandatory confirmation only if realized in objective temporal flow. This temporal and exclusive order establishes syntactical meaning in the form. By emphasizing the normativity, exclusivity and causality of temporal order which can be confirmed only though the aural realization/event of the musical work (and not by just reading the score), he can make the next step to the process of becoming. But he also has to demonstrate a persistent substrate in this process. In other words, he has to explain repetition as belonging to this process.

Therefore, if music also "must stem itself against the empty flood" of time, it must contain structures that reappear. Such structures make the flow of time subjectively perceivable. In his investigation of the notion of material in the Aesthetic Theory, Adorno makes a distinction between material and content (Inhalt) of music. Material is an elementary category similar to words, colors, and sounds. Content "is not external to musical time but essential to it, as time is essential to content; content is anything that transpires in time."77 Based on the correlation between irreversibility, content, and meaning, Adorno aims for a musical-logical notion of development (Entwicklung), because "pure change is not development." "78 Upon understanding "development" as "narrower" notion than "variation," he makes a logical transition to the concept of "musical logic." He defines the latter as "meaningful succession of the moments; that is, what comes earlier, and what comes later, must itself constitute the meaning or result from it." 79

Although Adorno explicitly interprets musical logic by applying the Hegelian notion of development (Entwicklung), ${ }^{80}$ the process he describes here ${ }^{81}$ is actually placed in the Hegelian "sphere of being," as "process of becoming" (Werden). According to Hegel's logic, development (Entwicklung) is placed in the "sphere of concept" (Begriff). Elsewhere, Adorno explicitly associates the dynamic element of Beethoven's musical form with the definition of the whole, as process of becoming ("Werden"). ${ }^{82}$ If we juxtapose different passages taken from Adorno's musical writings, it becomes evident that he relies on these notions as alternatives. His concept of the music's temporal irreversibility corresponds to Hegel's definition of time "in the sphere of being" in his Encyclopedia ("Mechanics"): Time is a permanent overcoming of unmediated instants. According to Adorno, the musical analogue to this self-reproducing process ${ }^{83}$ is "thematic work," actually 
motivic-thematic work. ${ }^{84}$ In so far, he can claim that "... Beethoven developed a musical essence (Seiende) out of nothingness in order to be able to redefine it as a process of becoming (Werdendes). ${ }^{, 85}$ Although some of his statements on the relationship between temporal irreversibility, process of becoming, and development are vague, Adorno - in contrast to Hegel— does not solely comprehend music as language of subjectivity on the level of the sensual; he aims to demonstrate posited structures in the musical form in order to ensure its normativity and exclusivity beyond the Hegelian permanent overcoming of unmediated instants. Therefore, he has to include a more extended structure in this process, such as the musical theme, or, even, the exposition in a sonata form. Only then could he highlight the notion of "work" as "identical category between philosophy and music," ${ }^{86}$ as development (Entwicklung). In other words, but in opposition to Hegel's conception of the musical theme, Adorno could then claim about the musical theme what Hegel claims about the concept: though the "development... the Concept remains at home with itself in the course of its process, and that the process does not posit anything new as regards content, but only brings forth an alteration of form. ${ }^{, 87}$ Hegel does not fully draw this conclusion about the musical theme; the only musical formation he conceptualizes remains the triad (Dreiklang). On the one hand, in the exploration of music in his Aesthetics, Hegel states that the theme remains a point of reference for the artist. The theme's "Recollection (Erinnerung) of the theme adopted is at the same time the artist's inner collection (Er-innerung) of himself, i.e., an inner conviction that he is the artist and can expatiate in the theme at will and move hither and thither in it." ${ }^{88}$ However, it seems that the theme, according to Adorno a "posited" (German, Gesetztes) essence, ${ }^{89}$ cannot become involved in the process of becoming; neither is it as elementary as the musical motive that it can move from nothingness (non-being) to being, nor does it possess the ability of self-explication as does the concept (Begriff) in the sphere of being. According to Hegel, on the one hand, the theme remains static to ensure that the musical work operates in a mode of being beyond pure improvisation. On the other hand, the music continues to remain in the sphere of the sensual (Sinnliches) as language of subjectivity.

How could Adorno find a music-philosophical mediation between the request for permanent growth and renewal of small musical structures, and the reappearance of the identical? How is this identical to be understood? It seems that such reappearances could undermine permanent growth, process of becoming and musical development. Reappearance of the main theme at the beginning of the recapitulation in a classicist sonata-form could imply, according to Adorno, "a salient spatial-symmetrical, architectural moment which becomes innermost alien within the temporal process." $" 90$

\section{From Process of Becoming to Temporal Totality in Pregnant Moments}

As mentioned, Adorno provides a hint in his essay, "Kriterien der neuen Musik:" "Similar to Hegel's logic, in musical logic, the notion of development (Entwicklung) means not absolute dynamic... but the being of this essence, in which something is being developed." ${ }^{91}$ Consequently, the transcendence of this difficulty lies in the conceptualization of the theme, which, like Hegel's concept, undergoes a formal, rather than substantive, change. So he can now demonstrate the Hegelian development in a musical structure, not as elementary as the motive, which, like Hegel's concept, is being developed (through variation, motivic-thematic working, etc.) and also remains identical, because the "'nature' of the concept... (is to remain) a development of itself..." 92 Adorno also applies this logic to the development sections of sonata forms that become "the focal point of the entire form" and the topos of "subjective reflection upon the theme which decides the fate of the theme." 93 However, Adorno goes even further in his multi-level dialectical understanding of musical time. His main 
concern is the temporal unfolding and coherence of even more extended parts that reappear, such as the recapitulation in a sonata form of Beethoven's middle period. Adorno attempts a hermeneutic of formal occurrences such as the early reappearance of the main theme over a dominant chord in the first movement of the Eroica Symphony; but this occurrence is also a delay of the appropriate harmonic introduction of the main theme and this delay emphasizes its subsequent reappearance in the tonic. In that way, the superposing of dominant chord and main theme express an emphatic standstill of past and future in symphonic time articulation. What makes at a beginning of a recapitulation in a classicist sonata-form of Beethoven's middle period the identical non-identical, apart from any harmonic or rhythmical changes, so that it can comply, as posited structure, with the request for permanent growth and the dynamic process of becoming? Time itself, replies Adorno, meaning the consequences of time-flow; "Time itself" is being identified by Adorno with time as change, time of musical events that stand in causal relationship in these paradigmatic forms of musical coherence. The reappearance of the main theme, that is, of sameness after the development-section, is caused by its opposite, dynamic change, and the explosive accumulated power from the exposition and development sections. Identity is introduced as a "tour de force," ${ }^{44}$ "as a result of a process, what has been once before." 95 And "time itself" that is abstract temporal flow in the context of process of becoming operates as beholder and indicator of change of meaning for identity: "All is identical, "the same." But the meaning of this identity is reflected as nonidentity. “... By virtue of this nonidentity of identity, music achieves an absolutely new relationship to the time within which each work transpires." 96 Therefore, according to him, even the avant-garde's aim during the early 1950s for a static music, which organizes itself, was illusory because of the fact that the musical work is being aurally realized in objective time. In other words, according to Adorno, there couldn't be real static music since in temporal flow "the identical becomes non-identical just as the non-identical can become the identical." ${ }^{97}$

But Adorno claims in addition that "The smallest detail can become the whole, because it is already (German, bereits) the whole." ${ }^{98}$ How is this possible and what does "already" mean? His final concern goes beyond the justification of the reappearance of the identical, as supporting and ensuring consistence and totality of the work, within the process of becoming. In other words, the problem lies not only in the hermeneutics of sameness within the process of becoming and within the self-reproducing permanence of this process. The problem is if this homogenous process, as moving factor, can consequently guarantee the totality of a work. Therefore, he attempts to find a temporal mediation between successive formal parts in this process, and work-wholeness, indeed to explain formal musical extension as consisting of the subsequent parts. But on the other hand, he states "musical form is its (the music's) temporal order." topos of a not schematic, but temporalized, totality for a musical work? Because the immanent difficulty of the musical work as a temporal object is that although it may constitute a paradoxical totality, this totality is never available and present as such, even retrospectively, after the musical work's "completion." It belongs then as aural event to the past and remains, perhaps for any philosophical approach, an enigmatic "object."

Kaehler, as well as Uehlein ${ }^{100}$ and Klein, ${ }^{101}$ observe this mediation in the permanent process of becoming and overcoming instants. Although, they refer to the problem of the recapitulation as "crux of the dynamic form," 102 these authors relate the dialectic of musical time mainly to the motivic-thematic working, as its musical analogue. This also refers to a notion of presence and openness ${ }^{103}$ in which the relationship between part and whole is also "becoming every moment" and also changes every moment. ${ }^{104}$ According to Adorno, on this relationship is based the unity of the whole which is "never external to the particular but emerges solely 
from its movement, or, rather, is this movement."105 Indeed, he states that "the special relationship between the systems of Beethoven and Hegel lies in the fact that the unity of the whole is to be understood merely as something mediated." 106 In addition to the explicit relation of motivic-thematic working to the above mentioned Hegelian logical principle, Adorno provides an analogue hint through his understanding of harmony; in the successive chords that change subsequently their functionality at the beginning of Beethoven's Waldstein-Sonata, he detects a permanent internal reproduction of the totality of a system, as "through-composed tonality." ${ }^{, 107}$ What is then this openness? It is the objective potentiality for permanent structural renewal and amendment of the particular in a dynamic future. This process can only be supported by the logic and extreme coherence of classicist motivic-thematic working, the "homogeneity of the material" that do not allow structural gaps. ${ }^{108}$ By insisting on the temporal micro-structure of the process of becoming, Uehlein and Klein solve the previously mentioned problem of mediation-between the request for permanent growth and renewal of small musical formations, and the reappearance of the identical - by referring to particular moments of transcendence, when not mediated through the process of becoming, even antithetical, formal parts appear instead of a recapitulation, as in the slow movement of Beethoven's string quartet, Opus 59/1. ${ }^{109}$ According to Adorno, this compositional solution constitutes the "possible which lies outside identity" as opposed to the expected, but not appearing, "real." 110 Uehlein ultimately observes the overcoming of this unresolved antinomy in the fragmentation of Beethoven's late style, while Adorno interprets it (the late style) as a departure from an "unbearable" problem that affects the composer's "critical genius."111

But perhaps there is another way to solve this antinomy, if there is a possibility of totality and consistency beyond the justification of temporal order through the repetition of identical parts and beyond the openness of the process in which the relationship between part and whole is also "becoming every moment." Justification of temporal order through repetition could namely also mean paratactic completion and does not guarantee strong organic relationship between the parts. Also the openness of the dynamic process of becoming refers to a potentiality without normative commitment to completion. Adorno actually radicalizes this relationship ${ }^{112}$ by referring to the Hegelian idea of mediation between whole and part ${ }^{113}$ for an additional reason: to point out the possibility that the temporal particular as integrated into the process of becoming may transcend succession towards totality - "The smallest can become the whole because it is already the whole."114 Hegel's thesis that the whole is the true does not have temporal content: The availability of the totality of the musical work should be temporal, while the mediation between whole and part is logical. Adorno's inversion and negation of Hegel's thesis, "the True is the whole"115 into the "whole is the untrue" whole, and to the fiction of the existence of any affirmative reference to it. ${ }^{117}$ From an ontological point of view, this is especially the case in the context of a temporal art par excellence. But even in works of extreme coherence, as are Beethoven's symphonic movements of his middle period, the mediation between part and whole is "becoming every moment." That means in the first place, in the permanent process of becoming there is always an available state or aspect of the whole. ${ }^{118}$ Uehlein interprets the problem of the unavailability of the whole focusing on the previously mentioned moments of "external"119 transcendence and on the fragmentation process, emerging in the composer's late works, "when the idea of totality as something already achieved had already become unbearable to his critical genius." ${ }^{.20}$ But internal transcendence and completion to totality in Beethoven's symphonic movements can only occur at nodal points that contain extreme accumulated power. Only then does the formal logical relationship also become temporal. These nodal points reflect not only the openness of this permanent self-reproducing process, but its intensity and gained as well as virtual content, 
traces of past and future, in which the "smallest is already the whole." In this context, Adorno localizes the intensive temporal type. He defines intensity as "mimesis achieved through unity and ceded by the multiplicity to totality, although this totality is not immediately present... the power accumulated in the totality is... restored to the detail.". symphonic movements of Beethoven, the first of the Eroica or of the Seventh, can be ideally so heard as lasting just a moment". And if, as he in another context claims, "the artifact achieves the impossible,"122 then his dialectics of musical time offer us an emphatic, hopeful and not "apocryphal semblance" of "undiminished unity," ${ }^{123}$ in temporal transcendence and instantaneous fulfillment.

\section{Notes}

1. Theodor W. Adorno, Klangfiguren: Musikalische Schriften I, Gesammelte Schriften 16 (cited hereafter as GS and volume number) (Frankfurt a. M.: Suhrkamp, 1997), 222.

2. Adorno, Musikalische Schriften III, GS 16: 628

3. Adorno, Musikalische Schriften V, GS 18: 52.

4. Adorno, Der getreue Korrepetitor, GS 15: 376.

5. Adorno, Aesthetic Theory. Eds. Gretel Adorno and Rolf Tiedemann, trans. Robert Hullot-Kentor (London: Continuum Press, 2002), 6 (cited hereafter as AT).

6. For a systematic account of the notion of the aesthetic moment, see Norbert Zimmermann, Der ästhetische Augenblick: Theodor W. Adornos Theorie der Zeitstruktur von Kunst und ästhetischer Erfahrung (Frankfurt a. M.: Peter Lang, 1989).

7. Berthold Hoeckner, Programming the Absolute (Princeton: Princeton University Press, 2006), 4, and "Der Moment und das Moment.”'Ed. Christian Berger, Musik jenseitz der Grenze der Sprache (Freiburg i. Br.: Rombach Verlag, 2004), 177, refers to the double meaning of the German word "Moment" as temporal (der Moment, Augenblick, Engl. instant) and material (das Moment, Bestandteil, Engl. part, element) category. Based on Frobenius's article, "Über das Zeitmaß Augenblick in Adornos Kunsttheorie," Archiv für Musikwissenschaft 36. 4 (1979): 279-304, and on his article, "Momentum/moment, instans/instant, Augenblick." Ed. Albrecht Riethmüller. Handwörterbuch der musikalischen Terminologie (Stuttgart: Franz Steiner Verlag, 1972), and on Adorno's use of both notions, I will consider "instant" and "moment" as alternatives. According to Adorno, the musical work inevitably unfolds in irreversible time and musical form is the corresponding order of aural events. Thus, the notion of "moment" as part has in a musical work a temporal meaning.

8. Adorno, AT, 80-81.

9. Works of "the truly symphonic Beethoven" (i.e., of his middle period), where "the temporal itself... aims, potentially, at its own transcendence, based on the strength of what occurs within them," Adorno, "On Some Relationships between Music and Painting," trans. Susan Gillespie, The Musical Quarterly 79, 1 (1995): 66.

10. Adorno, "Kriterien der neuen Musik," GS 16: 222.

11. Adorno, "On Some Relationships," 66, above, fn. No. 9.

12. Olivier Messiaen, Traité de rythme, de couleur, et d'ornithologie: (1949-1992) (Paris: Alfons Leduc, 1994), 1: 10.

13. Karlheinz Stockhausen, "Struktur und Erlebniszeit," Texte zur elektronischen und instrumentalen Musik 1 (DuMont Buchverlag: Köln, 1988), 87.

14. Adorno, AT, 244.

15. Karl Heinz Bohrer, Plötzlichkeit (Frankfurt a. M.: Suhrkamp, 1981), 48-67.

16. Adorno, "Form in der neuen Musik," GS 16: 620 (my translation), also "Zweite Nachtmusik," 52.

17. Lydia Goehr, "Doppelbewegung," in Dialektik der Freiheit: Frankfurter Adorno-Konferenz 2003, ed. Axel Honeth (Frankfurt a. M.: Suhrkamp, 2005), 313 (my translation).

18. Cf. Stockhausen's analysis of the second movement of Webern's String Quartet op. 28 in the previous mentioned text "Struktur und Erlebniszeit."

19. Above, fns. 12; 13.

20. Adorno, Beethoven: The Philosophy of Music, trans. E. Jephcott (Stanford: Stanford University Press, 1998), 164. See also below, 4. Sustainability versus Process of Becoming.

21. Adorno, "Late Style in Beethoven," Essays on Music, trans. S. Gillespie (Berkley: University of California Press, 2002$), 567$.

22. Adorno, AT, 81.

23. Ibid., 28.

24. Ibid.

25. Above, 230

26. See particularly the subchapter "Aesthetic Experience as Objective Understanding" in the "Draft Introduction" of the Aesthetic Theory. 
27. Adorno, AT, 244-5.

28. Bernard Berenson, Aesthetics and History (New York: Doubleday, 1948), quoted after Frobenius, "Über das Zeitmaß..." 281.

29. This convergence is also a synchronization because, according to Hegel, through the perception of the musical meter (bar) the I is being satisfied in rediscovering himself.

30. Immanuel Kant, Kritik der reinen Vernunft (Hamburg: Meiner, 1998), 209.

31. Adorno, Beethoven: The Philosophy of Music, 44. Adorno uses this expression when he points out that "it is exceedingly illuminating that Hegelian philosophy — whose categories can be applied without violence to every detail of a music that cannot possibly have been exposed to any Hegelian 'influence' in terms of the history of ideas - that this philosophy knows the reprise as does Beethoven's music: the last chapter of the Hegel's Phenomenology, the absolute knowledge, has no other content than to summarize the total work which claims to have already gained the identity of subject and object, in religion." Although the concept of musical form, as dialectical process of becoming, in German musical thought is influenced by Hegelian philosophy, we should not forget that this influence arises not from the philosopher's Aesthetics but from his Science of Logic, Phenomenology of Spirit and Encyclopedia.

32. Such approaches have actually an opposite direction. They aim to extend in temporal succession the perception, but also phenomenal display, of an ideally identical — since small and homogeneous - presence of a content, by including past and future through "retention" and "protention." However, in this case "continuity of identity" (Husserl) of the moments of a single tone or of the parts of a simple melody is presupposed. A holistic phenomenological approach forces extended formal parts, as an exposition of a sonata-from, to such a "continuity of identity," which can be grasped through "retention" or "recollection," cf. Zofia Lissa "Zeitstruktur und Zeiterlebnis im Musikwerk," Aufsätze zur Musikästhetik (Berlin: Henschelverlag, 1969), 64-65. The possibility of such a temporal extension (and perception) is of course also a cognitive problem, which is beyond the scope of this article. Adorno's approach aims to comprise a temporal extended, however coherent, content in the moment. Ilias Giannopoulos, "Challenging Husserl's 'Musical' Paradigms: On the Problem of Perception of Extended Musical Structures as Temporal Objects," Glimpse 16 (2015): 41-46.

33. Frobenius, "Über das Zeitmaß."

34. Walter Benjamin, "Doctrine of the Similar," Selected Writings, Volume 2 (1927-1934), trans. Rodney Livingstone, ed. Michael W. Jennings (Cambridge, Mass.: The Belknap Press of Harvard University Press, 1999), 695-6.

35. Emphasis mine. Adorno considers constellation (and configuration) as both centripetal and centrifugal formal principles for musical structures (e.g., AT, 197) and for his own writings. However, it would be beyond the scope of this article to explore the relevance of these aspects of the just mentioned notions to the idea of instantaneous totality - the meaning of constellation in the above mentioned writings of Benjamin.

36. Frobenius, "Über das Zeitmaß," 293.

37. Ibid.

38. Adorno, AT, 53.

39. Adorno points out art's double character as both autonomous phenomenon and fait social AT, $5 ; 225-8$.

40. Ibid., 104.

41. Ibid., 4.

42. Ibid.

43. Ibid., 55. 125.

44. Adorno, Philosophy of Modern Music, trans. Anne Mitchell and Wesley Blomster (New York: The Seabury Press, 1980),

45. Adorno, AT, 100.

46. Ibid., 245.

47. Ibid.

48. Ibid., 345-8 where he approaches aesthetic experience "as Objective Understanding."

49. Above, fn. 45.

50. Emphasis mine.

51. However, according to Adorno, musical material is "sedimented spirit," Philosophy of Modern Music, 39.

52. Adorno, AT, 7.

53. Ibid., 176.

54. Ibid.

55. Ibid.

56. Benjamin, “Goethe's Elective Affinities," Selected Writings, Volume 1 (1913-1926), trans. Rodney Livingstone (Cambridge, Mass.: The Belknap Press of Harvard University Press, 1996), 340.

57. Adorno, "On Some Relationships," 69-70.

58. Adorno, AT, 84.

59. Above, 2. From Subjective to Objective Moment.

60. Adorno, Beethoven: Philosophie der Musik, 78.

61. Adorno, "On Some Relationships," 66.

62. Adorno, ibid.

63. Klaus Kaehler, “Aspekte des Zeitproblems in der Musikphilosophie Theodor W. Adornos,” Mit den Ohren denken. Eds. 
Richard Klein and Klaus-Steffen Mahnkopf (Frankfurt a. M.: Suhrkamp, 1998), 37-38.

64. Adorno, Philosophy of New Music, trans. Robert Hullot-Kentor (Minneapolis: University of Minnesota Press, 2006), 47; Adorno, AT, 23; Adorno, "Kriterien der neuen Musik," 222.

65. Adorno, "Kriterien der neuen Musik," 222. Adorno's claim opposes the efforts of the Avant-garde of the 50's to create static music.

66. Adorno, AT, 28, also above, fns. 24-25.

67. Carl Dahlhaus. "Zur Zeitstruktur der Musik." Gesammelte Schriften (GS) 4: 336; "Zur Phänomenologie der Musik." GS 1: 510 (Laaber: Laaber Verlag, 2004).

68. Adorno, AT, 176.

69. Cf. above, fn. 29.

70. Adorno, Philosophy of Modern Music, 193; 197.

71. Adorno, "Form in der neuen Musik," Musikalische Schriften III, GS 16: 613 (my translation).

72. Adorno's statement is quite idiosyncratic concerning the absence of "any kind of repetition" in this piece. What perhaps could somehow support Adorno's claim is the fact that the second of the two themes is not being repeated in the quite shortened recapitulation.

73. Adorno, Der getreue Korrepetitor, 199 (my translation).

74. Adorno, "The Aging of New Music," Essays on Music, ed. Richard Leppert, trans. Suzan H. Gillespie (Berkeley: University of California Press, 2002).

75. Adorno, "On Some Relationships," 66.

76. Adorno, "Form in der neuen Musik," 607.

77. Adorno, AT, 148.

78. Adorno, "Kriterien der neuen Musik," 223 (my translation).

79. Adorno, Beethoven: The Philosophy of Music, 67.

80. Adorno, "Kriterien der neuen Musik," 117. Adorno associates "similar to Hegel's Logic" ("nicht anders als in Hegel's Logic"), the "notion of development" ("Begriff der Entwicklung") with "the being of that, within which something is being developed" ("das Sein dessen in sich, was entwickelt wird"). And this "solid structure" ("festes," e.g., a musical theme) is an analogue to the Hegelian "concept" (Begriff), my translation.

81. Adorno, Beethoven: The Philosophy of Music, 67.

82. Adorno, Der getreue Korrepetitor, 198.

83. Adorno, Beethoven: Philosophie der Musik, 33.

84. Adorno, Beethoven: The Philosophy of Music, 12: "What is called conceptual exertion or work in Hegel is thematic work in music," ibid. This work is since Haydn's classical style also motivic.

85. Adorno, Philosophy of Modern Music, 77.

86. Adorno, Beethoven: The Philosophy of Music, 12.

87. Hegel, G. W. F., The Encyclopedia Logic, trans. T. F. Geraets, W. A. Suchting (Indianapolis/Cambridge: Hackett Publishing Company, Inc., 1991), 238.

88. Hegel, Aesthetics: Lectures on Fine Art Vol. II, trans. T. M. Knox (Oxford: Clarendon Press, 1975), 897.

89. Adorno also refers to the Greek etymology of the word theme as $\tau \varepsilon \theta \varepsilon \mu \varepsilon \dot{v}$ o, "Kriterien de neuen Musik," 217.

90. Adorno, "Form in der neuen Musik," 612 (my translation).

91. Adorno, "Kriterien de neuen Musik," 217-8 (my translation). Also above, fn. 80

92. Hegel, The Encyclopedia Logic, 238.

93. Adorno, Philosophy of Modern Music, 55.

94. Adorno, "Form in der neuen Musik," 612.

95. Adorno, Beethoven: The Philosophy of Music, 44.

96. Adorno, Philosophy of New Music, 46. Also "On Some Relationships," 69 and "Anweisung zum Hören neuer Musik," Der getreue Korrepetitor, 200.

97. Adorno, "The Aging of New Music," 188.

98. Adorno, Beethoven: The Philosophy of Music, 164.

99. Adorno, "On Some Relationships," 66.

100. Friedrich Uehlein. "Beethovens Musik ist die Hegelsche Philosophie: sie ist aber zugleich wahrer..." Eds. Richard Klein and Klaus-Steffen Mahnkopf. Mit den Ohren denken (Frankfurt a. M.: Suhrkamp, 1998), 222-3.

101. Richard Klein. "Prozessualität und Zuständlichkeit: Konstruktionen musikalischer Zeiterfahrung.” Ed. Otto Kolleritsch Abschied in die Gegenwart: Teleologie und Zuständlichkeit in der Musik, Studien zur Wertungsforschung 35 (Wien: Universal-Edition, 1998), 182.

102. Adorno, Beethoven: Philosophie der Musik, 78 (my translation).

103. Cf. Klein, 182.

104. Adorno, Der getreue Korrepetitor, 198.

105. Adorno, Beethoven: The Philosophy of Music, 24.

106. Ibid., 13.

107. Adorno, Beethoven: Philosophie der Musik, 90 (my translation).

108. Adorno, Beethoven: The Philosophy of Music, 23; also above, ft. 9. 
109. Uehlein, 226; Klein, 184-5; 203.

110. Adorno, ibid., 14.

111. Ibid.

112. Beethoven: Philosophie der Musik, 34-36.

113. However, in Hegel's Logic, this relationship is not temporal.

114. Adorno, ibid., 236 (my translation).

115. Hegel, Phenomenology of Spirit. Trans. A. V. Miller (New York: Oxford University Press, 1977), 11.

116. Adorno, Minima Moralia, GS 4: 55.

117. Adorno,"Erfahrungsgehalt," Drei Studien zu Hegel, GS 5: 324.

118. Uehlein, 224.

119. This distinction stems from Klein, 203.

120. Adorno, Beethoven: Philosophy of Music, 14; Uehlein, 224-7.

121. Adorno, AT, 187.

122. Ibid., 162.

123. Ibid., 105.

\section{Works cited}

Adorno, Theodor W. Aesthetic Theory. Eds. Gretel Adorno and Rolf Tiedemann. Trans. Robert Hullot-Kentor. London: Continuum Press, 2002.

---. "The Aging of New Music." Essays on Music. Ed. Richard Leppert. Trans. Suzan H. Gillespie. Berkeley: University of California Press, 2002. 181-202.

---. Beethoven: Philosophie der Musik. Nachgelassene Schriften I/1. Frankfurt a. M.: Suhrkamp, 1999.

---. Beethoven: Philosophy of Music. Trans. Edmund Jephcott. Stanford: Stanford University Press, 1998.

---. Dialektik der Aufklärung. Gesammelte Schriften 3. Frankfurt a. M.: Suhrkamp, 1997.

---. Klangfiguren: Musikalische Schriften I. Gesammelte Schriften 16. Frankfurt a. M.: Suhrkamp, 1997.

--- "Late Style in Beethoven." Essays on Music. Ed. Richard Leppert. Trans. Susan H. Gillespie. Berkeley: University of California Press, 2002. 564-83.

---. Mahler: A Musical Physiognomy. Trans. Edmund Jephcott. Chicago: The University of Chicago Press, 1992.

---. Minima Moralia. Gesammelte Schriften 4. Frankfurt a. M.: Suhrkamp, 1997.

---. “On Some Relationships between Music and Painting.” Trans. Susan Gillespie. The Musical Quarterly 79.1 (1995): $263-84$.

---. Philosophy of Modern Music. Trans. Anne Mitchell and Wesley Blomster. New York: The Seabury Press, 1980.

---. Philosophy of New Music. Trans. Robert Hullot-Kentor. Minneapolis: University of Minnesota Press, 2006.

---. "Skoteinos oder Wie zu Lesen sei.” Drei Studien zu Hegel. Gesammelte Schriften 5. Frankfurt a. M.: Suhrkamp, 1997.

---. "Über die musikalische Verwendung des Radios." Der getreue Korrepetitor. Gesammelte Schriften 15. Frankfurt a. M.: Suhrkamp, 1997.

---."Zweite Nachtmusik.” Musikalische Schriften V. Gesammelte Schriften 18. Frankfurt a. M.: Suhrkamp, 1997.

Benjamin, Walter. "Doctrine of the Similar." Selected Writings, Volume 2 (1927-1934). Trans. Rodney Livingstone, ed. Michael W. Jennings. Cambridge, Mass.: The Belknap Press of Harvard University Press, 1999. 694-711.

---. "Goethe's Elective Affinities." Selected Writings, Volume 1 (1913-1926). Trans. Rodney Livingstone, ed. Michael W. Jennings. Cambridge, Mass.: The Belknap Press of Harvard University Press, 1996. 297-360.

Bohrer, Karl Heinz. Plötzlichkeit. Frankfurt a. M.: Suhrkamp, 1981.

Dahlhaus, Carl. "Zur Phänomenologie der Musik.” Gesammelte Schriften 1. Laaber: Laaber Verlag, 2000. 510-8.

---. "Zur Zeitstruktur der Musik.” Gesammelte Schriften 4. Laaber: Laaber Verlag, 2004. 334-8.

Frobenius,Wolf. "Momentum/moment, instans/instant, Augenblick." Handwörterbuch der musikalischen Terminologie. Ed. Albrecht Riethmüller. Stuttgart: Franz Steiner Verlag, 1972.

---. “Über das Zeitmaß Augenblick in Adornos Kunsttheorie.” Archiv für Musikwissenschaft 36. 4 (1979): 279-304.

Giannopoulos, Ilias. “Challenging Husserl's 'Musical' Paradigms: On the Problem of Perception of Extended Musical Structures as Temporal Objects." Glimpse 16 (2015): 41-46.

Goehr, Lydia. "Doppelbewegung." Dialektik der Freiheit: Frankfurter Adorno-Konferenz 2003. Ed. Axel Honeth. Frankfurt a. M.: Suhrkamp, 2005. 279-317.

Hegel, G. W. F. Aesthetics: Lectures on Fine Art Vol. II. Trans. T. M. Knox. Oxford: Clarendon Press, 1975.

---. The Encyclopedia Logic. Trans. T. F. Geraets, W. A. Suchting. Indianapolis/Cambridge: Hackett Publishing Company, Inc., 1991. 
---. Phenomenology of Spirit. Trans. A. V. Miller. New York: Oxford University Press, 1977.

Hoeckner, Berthold. "Der Moment und das Moment." Ed. Christian Berger. Musik jenseitz der Grenze der Sprache. Freiburg i. Br.: Rombach Verlag, 2004. 173-88.

---. Programming the Absolute. Princeton: Princeton University Press, 2006.

Kaehler, Klaus. “Aspekte des Zeitproblems in der Musikphilosophie Theodor W. Adornos.” Eds. Richard Klein and Klaus-Steffen Mahnkopf. Mit den Ohren denken. Frankfurt a. M.: Suhrkamp, 1998. 37-51.

Kant, Immanuel. Kritik der reinen Vernunft. Hamburg: Felix Meiner Verlag, 1998.

Klein, Richard. "Prozessualität und Zuständlichkeit: Konstruktionen musikalischer Zeiterfahrung." Ed. Otto Kolleritsch. Abschied in die Gegenwart: Teleologie und Zuständlichkeit in der Musik. Studien zur Wertungsforschung 35. Wien: Universal-Edition, 1998. 180-210.

Lessing, G. E. Laocoon: An Essay on the Limits of Painting and Poetry. Trans. E. A. McCormick. New York: Bobbs-Merrill, 1962.

Lissa, Zofia. "Zeitstruktur und Zeiterlebnis im Musikwerk.” Aufsätze zur Musikästhetik. Berlin: Henschelverlag, 1969. 51-69.

Messiaen, Olivier. Traité de rythme, de couleur, et d'ornithologie: (1949-1992). Paris: Alfons Leduc, 1994.

Stockhausen, Karlheinz. Texte zur elektronischen und instrumentalen Musik 1. Köln: DuMont Buchverlag, 1988.

Uehlein, Friedrich. "Beethovens Musik ist die Hegelsche Philosophie: sie ist aber zugleich wahrer..." Mit den Ohren denken. Eds. Richard Klein and Klaus-Steffen Mahnkopf. Frankfurt a. M.: Suhrkamp, 1998. 206-28.

Zimmermann, Norbert. Der ästhetische Augenblick: Theodor W. Adornos Theorie der Zeitstruktur von Kunst und ästhetischer Erfahrung. Frankfurt a. M.: Peter Lang, 1989. 